August 2007

\title{
The World Court's Fractured Ruling on Genocide
}

David Scheffer

Follow this and additional works at: https://digitalcommons.usf.edu/gsp

\section{Recommended Citation}

Scheffer, David (2007) "The World Court's Fractured Ruling on Genocide," Genocide Studies and Prevention: An International Journal: Vol. 2: Iss. 2: Article 3.

Available at: https://digitalcommons.usf.edu/gsp/vol2/iss2/3

This Articles is brought to you for free and open access by the Open Access Journals at Digital Commons @ University of South Florida. It has been accepted for inclusion in Genocide Studies and Prevention: An International Journal by an authorized editor of Digital Commons @ University of South Florida. For more information, please contact digitalcommons@usf.edu. 


\title{
The World Court's Fractured Ruling on Genocide
}

\author{
David Scheffer \\ Mayer, Brown, Rowe \& Maw / Robert A. Helman Professor of \\ Law and Director, Center for International Human Rights, \\ Northwestern University School of Law
}

\begin{abstract}
In February 2007 the International Court of Justice (ICJ) delivered a lengthy judgment in a major genocide case, Bosnia v. Serbia, arising from the Balkans war of the early 1990s. Two of the ICJ's unprecedented rulings are major advancements for enforcement of the Convention on the Prevention and Punishment of the Crime of Genocide (UNCG). First, the Serbian state was found to be in violation of its art. 1 obligation to prevent and punish the crime of genocide. This is a significant boost for both the UNCG and the emerging legal principle of the responsibility to protect civilian populations at risk of atrocity crimes. Second, the ICJ ruled that a state, and not only individuals, can be found responsible for genocide, conspiracy to commit genocide, direct and public incitement to commit genocide, attempt to commit genocide, or complicity in genocide. Despite these encouraging rulings, however, the ICJ's majority judgment exhibits several serious shortcomings. The first is the majority's failure to develop a state-centric methodology to determine any inference of genocidal intent by the Serbian government. The judges failed to obtain and examine evidence that might have pointed demonstrably to such inference of intent. The second is the majority's misinterpretation of the crime of complicity in genocide, particularly as it relates to state responsibility: the majority erroneously equated complicity with aiding and abetting and failed to distinguish, in the context of complicity, between specific intent to commit genocide and the motive to do so. Third, the ICJ has missed an opportunity to point out emphatically that its finding on genocide, or the lack thereof, with respect to the state of Serbia reveals a significant gap in international law. While constructively finding that the UNCG can trigger state responsibility for genocide, the ICJ's judgment shows how deficient international law is in holding states responsible for crimes against humanity and war crimes. One is left pondering the "what ifs" in the result and wondering how the international community can now move forward to draft new treaties that would establish the means to enforce state responsibility for all atrocity crimes.
\end{abstract}

The multiplicity of issues erupting from the recent judgment of the International Court of Justice (ICJ) in the Case concerning the Application of the Convention on the Prevention and Punishment of the Crime of Genocide (Bosnia and Herzegovina $v$. Serbia and Montenegro $)^{1}$ leaves one pondering "what if?" with the turn of every one of the 171 single-spaced pages of the majority's views. What if there had been a judgment by the International Criminal Tribunal for the Former Yugoslavia (ICTY) in Miloševic ${ }^{2}$ following his lengthy trial on charges of genocide, a profoundly important judgment aborted, shortly before the trial's end, by Slobodan Milošević's sudden death? What if certain evidence provided by the Serbian government to the ICTY in Miloševic'

David Scheffer, "The World Court's Fractured Ruling on Genocide." Genocide Studies and Prevention 2, 2 (August 2007): 123-136. (C) 2007 Genocide Studies and Prevention.

doi: $10.3138 / g s p / 002$ 
had been turned over to the ICJ for its own study? What if the ICJ had had the jurisdiction, in Bosnia $v$. Serbia, to examine state responsibility for crimes against humanity and war crimes?

Among a few of the dissenting judges, one is inspired to ask, "Whither common sense in genocide litigation?" Though good-faith analysis abounds in both the majority's and the dissenting judges' writings, they were constrained by the exceptionally narrow prism of genocide through which all responsibility was judged. There is an almost surreal texture to much of the majority judgment, in particular-as if the judges were mesmerized by the fog of the evidence presented to them rather than being enlightened by the overall reality of what occurred in Bosnia and Herzegovina from 1991 through 1995, which the whole world witnessed, and by the way governments, and not just individuals, dictated the carnage. I write these words knowing full well that the judges are duty bound to evaluate the evidence, or lack thereof, and not to speculate as to the facts or extend themselves beyond the jurisdictional boundaries of the parties' applications. But in the realm of genocide, the ICJ lost itself in a thicket of legal reasoning strangely distant from reality.

There is no question that the ICJ's majority judgment contains two very significant advancements for the enforcement of the Convention on the Prevention and Punishment of the Crime of Genocide (UNCG). ${ }^{3}$ The first such development is the unprecedented finding that Serbia failed in its art. 1 obligation to prevent and punish the crime of genocide. ${ }^{4}$ The emerging legal principle of the responsibility to protect civilian populations at risk of atrocity $\operatorname{crimes}^{5}$ will be greatly strengthened as governments weigh the possible consequences of failing to take action to prevent genocide, particularly when instructed to do so in ICJ provisional measures, or of failing to punish those individuals responsible for the crime. It is to be hoped that the ICJ's judgment will inspire national legal systems-and, ultimately, lead to future legislation and judicial decisions - to hold their own governments to the high standard of prevention and punishment now reflected in the ICJ's enforcement of the UNCG. The judgment may also inspire further applications to the ICJ to address other failures by states parties to the UNCG to exercise their responsibility to prevent and punish the crime of genocide.

The second critical achievement of the majority judgment is the recognition that a state, not just an individual, can be held responsible under the UNCG for genocide, conspiracy to commit genocide, direct and public incitement to commit genocide, attempt to commit genocide, or complicity in genocide. ${ }^{6}$ The confusion over whether the convention reaches to state responsibility, particularly beyond art. 1 obligations, has been ended by the majority. ${ }^{7}$ Several judges disagreed, ${ }^{8}$ and scholars will doubtless continue to debate the point. But I for one am relieved that the ICJ delivered the fundamental reality check that, obviously and logically, the UNCG covers state responsibility. The alternative interpretation - that the drafting history and text of the convention reflect no such intention-is important to reflect upon, but it is a perverse distortion of how, in most instances, individuals actually commit the crime of genocide: they do so as agents of a state, which cannot itself escape responsibility without rendering the UNCG little more than a shield for state-sponsored genocide.

In this article, however, I want to focus on some serious shortcomings in the ICJ's majority judgment in Bosnia $v$. Serbia. The first is the majority's failure to infer genocidal intent on the part of the Serbian government and to obtain and examine evidence that might have pointed demonstrably at least to such inference of intent. The second is the majority's interpretation of the crime of complicity in genocide, 
particularly as it relates to state responsibility. Third, the elephant in the room that cripples the ICJ's ability to properly determine state responsibility beyond the UNCG is the lack of any comparable international treaty covering crimes against humanity and war crimes. The result is an artificial exercise in legal masochism that has the practical effect of absolving a government of its responsibility for atrocity crimes simply because codified criteria for the crime of genocide have not been met. Nothing exists in treaty law to bridge the enormous gap between the criminal law covering individuals and the void that enables outrageous state-sponsored or stateinfluenced conduct (other than genocide) to go unchecked in courts of law.

\section{The ICJ's Failure to Infer the Intent to Commit Genocide}

Rather than investigate and analyze the totality of violent events that engulfed the people of Bosnia and Herzegovina between 1991 and 1995, the ICJ chose to disaggregate its analysis into an investigation of whether, for each individual incident presented as evidence to the court, the specific intent required for a finding of the crime of genocide could be conclusively shown. ${ }^{9}$ Central to the court's failure to establish specific intent was the fact that it did not find such necessary intent for any individual engaged in any specific incident other than the Srebrenica massacres of July 1995. The majority relied heavily on the jurisprudence of the ICTY, which prosecutes only individuals and which has not found the requisite intent to commit genocide except in the Krstic judgment pertaining to Srebrenica. ${ }^{10}$ The high standard of proof for establishing the specific intent of genocide under principles of individual criminal responsibility does not necessarily hold for state responsibility, where the standard of proof is necessarily of a different character than that applied to individual perpetrators confronting a loss of liberty, or possibly even a death sentence, as punishment.

At one point the ICJ quotes the famous dictum from the Nuremberg trials, that "[c]rimes against international law are committed by men, not by abstract entities..."11 Yet the majority shrank from the equally important truth that it had largely established (albeit with the terminology of state responsibility) earlier in its judgment: atrocity crimes are committed by governments and other abstract entities, and only rarely by men alone. In order to properly analyze whether a government or any part thereof acted with the specific intent to commit genocide, the most plausible methodology is to establish the inference of specific intent by examining the evidence of a multiplicity and pattern of events and then understanding how such events can be explained by exposing direct and indirect linkages to the suspect government. A mystery tour through the psyches of political or military leaders is not essential to the task of discovering the requisite mens rea of inferential intent for state-sponsored genocide.

There is nothing revolutionary in establishing the inference of intent as the mens rea of genocide. The ad hoc tribunals have been discovering inferred intent of genocide with respect to individuals for years. ${ }^{12}$ There is no reason that the ICJ could not have employed a similar methodology, adjusted for state-centric analysis, with respect to Serbia and Montenegro. Unfortunately, the majority searched for the inference of intent as if it were discoverable only by examining individual perpetrators (in the spirit of the ad hoc tribunals) and determining whether and how each person's intentions could be inferred. Failing to meet that identical test for a state, the ICJ surrendered the playing field to the complexity of the crime itself. The court failed to employ any methodology that seeks evidence of the inference of intent to commit 
genocide in the actions, events, circumstances, policies, omissions, and rhetoric of a government acting in its collective capacity, notwithstanding that an individual leader may be targeted for criminal responsibility before a separate court of criminal jurisdiction.

Significantly, as discussed above, the majority judgment confirms a key principle: there is authority in the UNCG for the finding of state responsibility for the crime of genocide, albeit not as a matter of criminal culpability but only as "the responsibility of States simpliciter." ${ }^{13}$ In critical part,

\begin{abstract}
Accordingly, having considered the various arguments, the Court affirms that the Contracting Parties are bound by the obligation under the Convention not to commit, through their organs or persons or groups whose conduct is attributable to them, genocide and the other acts enumerated in Article III. Thus if an organ of the State, or a person or group whose acts are legally attributable to the State, commits any of the acts proscribed by Article III of the Convention, the international responsibility of that State is incurred. ${ }^{14}$
\end{abstract}

The logic behind this finding does not point only to the broader interpretation of the UNCG as a legal instrument of accountability for states as well as individuals. There also is the pragmatic reality that the convention can achieve this broader interpretation only if the specific-intent requirement for the crime of genocide is one that can be inferred with respect to the overall conduct (at least extending beyond individual incidents to an aggregate of incidents) of a government bound by the treaty.

However, the majority in Bosnia $v$. Serbia concludes that, "save for the events of July 1995 at Srebrenica, the necessary intent required to constitute genocide has not been conclusively shown in relation to each specific intent." ${ }^{15}$ They establish three avenues by which such evidence could be demonstrated: (1) on the part of the individual perpetrators, although that would not necessarily demonstrate governmental responsibility; (2) on the basis of a concerted plan; or (3) on the basis that the events reviewed in the matter reveal a consistent pattern of conduct that can only point to the existence of such intent. ${ }^{16}$ Because the focus of intent was shifted from the individual perpetrators (option 1) to higher governmental authority or to the Serbian government itself (options 2 and 3), Bosnia had to show either an official statement of aims reflecting a genocidal intent or a pattern of conduct. The court found unpersuasive the evidence presented under either requirement. But the court suffered from its own investigative shortcomings and its inability, or unwillingness, to connect the dots with the kind of reasoned analysis one might have expected of the highest court of international law.

The key paragraphs (370-76) of the majority's decision hardly demonstrate the kind of rigorous investigative and analytical exercise required to establish whether a government's specific intent to commit genocide can be inferred. As the ICJ notes, Bosnia's assertions shift from the intent of individual perpetrators to the intent of higher authority. ${ }^{17} \mathrm{~A}$ singular truth about inference of intent is that clear and unambiguous statements of intent, including in any official statement of aims, likely will not be found. So when the court noticed that, in Republika Srpska President Momcilo Krajisnik's Decision on Strategic Goals of 12 May 1992, the "objectives do not include the elimination of the Bosnian Muslim population," one gropes for a reality check. Would it surprise anyone that there is no such blatant statement in writing?! Of course the document "does not necessarily involve the intent to destroy in whole or in part the Muslim population in the enclaves," as the majority held (emphasis added). 
But if one combines the highly suggestive (shall we say coded?) signals sent in that particular document with the cascade of murderous and destructive operations on the ground over a number of years, the uniquely integrated character of Serb and Bosnian Serb military forces, and the many journeys of Radovan Karadžić and Ratko Mladić back and forth to Belgrade to check in with the Serb leadership, the strong possibility, if not reality, of genocide knocks very loudly at the ICJ's door.

The court bends over backward to presume a different intent by the Bosnian Serb leadership - namely, the expulsion of the Bosnian Muslims and other communities. ${ }^{18}$ That discretionary choice could have gone the other way, with the court leaning toward a presumption of intent to commit genocide on the part of the Bosnian Serb leaders and then investigating their linkages to the Belgrade leadership. The court notes that the ICTY has not characterized the Strategic Goals as genocidal, which certainly is interesting, but in the context of state responsibility the ICTY's findings are a footnote. The real story, which the ICJ failed to investigate, is how the Strategic Goals form part of a larger mosaic of policy statements, leadership rhetoric, and collaborative relationships and conduct (including the failure to act at critical stages) between Belgrade and Pale, and their respective militaries, over a number of years. ${ }^{19}$ This is where the evidence held by the ICTY in the Milošević case might have proved critical, if only the ICJ had been more aggressive and more patient in seeking to acquire it. ${ }^{20}$ What if, for example, the ICJ had dared to subpoena Serbia for the critical minutes of its Supreme Defense Council? What if the ICJ had sought the assistance of major governments to pressure Belgrade to authorize the ICTY to release the Serbian government documents it held in the Milošević case to the ICJ, in their entirety and unredacted? Under the Statute of the ICJ, the court has clear authority to investigate and proactively seek such evidence, ${ }^{21}$ yet there appears to have been no discernible action on the part of the court to obtain this evidence. ${ }^{22}$ Sadly, the passive character of the ICJ's investigative endeavors reflects an entrenched habit.

There also was no attempt by the ICJ to examine the totality of the evidence presented during the Milošević trial and determine whether such evidence might point to Serbian state responsibility for actions that might have been interpreted as part of a genocidal campaign in Bosnia. The fact that Slobodan Miloševic died before judgment was rendered in his trial does not negate the existence of such evidence. His untimely death simply means that a final judgment will never be reached on his personal conduct. But there is a wealth of evidence from his trial that the ICJ, examining state conduct, would find very instructive. The Miloševic' trial testimony of former US general Wesley Clark, which recounts his conversation with Miloševic during the Dayton peace talks in late $1995,{ }^{23}$ is used by the ICJ majority only to help prove that Serbia failed in its state responsibility to prevent the genocide at Srebrenica. ${ }^{24}$ Yet Clark's exchange with Milošević could have pointed to broader state responsibility behind the genocide at Srebrenica if examined as part of a larger tapestry of statements and actions. ${ }^{25}$

Another example of highly suspect Serbian connections with the Srebrenica genocide involved the actions of the "Scorpions," their description as "a unit of Ministry of Interiors [sic] of Serbia," and a videotape showing a Scorpion paramilitary unit leading six Muslim prisoners-young men and boys-off to their deaths. ${ }^{26}$ Presented in this context was the declaration made by the Council of Ministers of Serbia on 15 June 2005, which read in part,

Those who committed the killings in Srebrenica, as well as those who ordered and organized that massacre represented neither Serbia nor Montenegro, but an 
undemocratic regime of terror and death, against whom the majority of citizens of Serbia and Montenegro put up the strongest resistance. ${ }^{27}$

That declaration should have set off some alarm bells in the Peace Palace, warning the court to dig deeper, much deeper, to find evidence of Serbian government complicity, at a minimum, in the genocide at Srebrenica and perhaps beyond. Instead, the ICJ majority considered the statement to be a political one that does not constitute an admission of responsibility for the Srebrenica massacres. ${ }^{28}$

The easiest analysis of the Clark-Miloševic exchange and the actions of the Scorpions at Srebrenica is to take them in isolation, as the majority did, and to show how neither demonstrates conclusively either direct or inferential genocidal intent. The harder, but more important, analysis would be to weave these two events into a more comprehensive and coherent study of the years of collaborative actions and omissions facilitating genocide that may have existed between some Bosnian Serb leaders and some Serbian leaders in Belgrade. The ICJ analysis is reminiscent of how the International Commission of Inquiry on Darfur looked at certain isolated events and the identities of certain victims and concluded that neither genocide nor even any genocidal policy existed with respect to Darfur. ${ }^{29}$ If one were to search for an easy way for judges and lawyers to avoid the reality of state responsibility for genocide, both the ICJ majority and the International Commission of Inquiry on Darfur discovered it in spades-to the detriment of genocide studies, UNCG enforcement, and genocide prevention for years to come.

The ICJ's third option for discovering the specific intent of a state is framed with an almost impossible standard of proof:

The dolus specialis, the specific intent to destroy the group in whole or in part, has to be convincingly shown by reference to particular circumstances, unless a general plan to that end can be convincingly demonstrated to exist; and for a pattern of conduct to be accepted as evidence of its existence, it would have to be such that it could only point to the existence of such intent. ${ }^{30}$

One might interpret this view to mean that only the intent to commit genocide must explain the atrocity. There are clear precedents of genocide in world history, but to state that a pattern of conduct can be ruled as genocide provided that its only characteristic is that of genocide would be patently absurd. One must presume that, while the ICJ would require that an intent to commit genocide be demonstrated in order to hold a state responsible for genocide, the elements of crimes against humanity and war crimes might also be found relating to the same situation under scrutiny. Unfortunately, the ICJ may have delivered the impression-if not an outright ruling - that only genocide must constitute the state's intended action.

The ICJ dismisses this third option by concluding that its failure to find the specific intent of genocide by the perpetrators of individual atrocities complained of by Bosnia, as well as the ICTY's record of no convictions on genocide other than for Srebrenica, fails to establish intent on the part of the Serbian government. ${ }^{31}$ There is no attempt by the ICJ to understand what the aggregate of "widespread and serious atrocities" might mean in interpreting a government's overall policy and the inferences that could be drawn from it. The result of such an exercise may be that no inferential intent to commit genocide existed in Belgrade from 1991 to 1995. But one would have expected the ICJ to make a serious effort to determine any such inferential intent, even if that meant traversing new terrain in ICJ jurisprudence to create a methodology that not only is faithful to the totality of facts but also understands that there is a distinction 
between how one judges a government's performance and how one judges that of an individual perpetrator. As ICJ Vice-President Al-Khasawneh writes in dissent,

[T] he Court has refused to infer genocidal intent from the consistent pattern of conduct in Bosnia and Herzegovina. In its reasoning, the Court relies heavily on several arguments, each of which is inadequate for the purpose, and contradictory to the consistent jurisprudence of the international criminal tribunals. ${ }^{32}$

Essentially, the ICJ sought to find governmental responsibility by building a pyramid of incidents revealing the specific intent to commit genocide-and only genocide-by individual perpetrators, all of whom must be associated with the respondent government, Serbia. A far more pragmatic methodology would be to require proof of the inference of genocidal intent through the totality of atrocities and how they could be plausibly understood as the natural consequence of specific intent within and by the government to commit genocide.

\section{Complicity in Genocide}

The ICJ's failure to conduct a proper examination of the inference of intent to commit genocide is directly tied to another significant failure: the court's flawed examination of complicity in the commission of genocide. I would argue that the two exercisesestablishing the inference of a government's intent and finding complicity—are deeply intertwined analytical exercises and can point to state responsibility if properly undertaken.

The court sought to interpret complicity by referring to the International Law Commission's proposed articles on Responsibility of States for Internationally Wrongful Acts (particularly art. 16), ${ }^{33}$ then erroneously using that document to define complicity of a state in committing genocide. ${ }^{34}$ The two bodies of principles-the first not having been brought into force by treaty law or enforceable as customary international law, the second being both treaty law and customary international laware apples and oranges. Even if some may conclude that the ILC was attempting to establish state responsibility for criminal conduct, including genocide, in drafting the articles on state responsibility, the ILC did not, and has not yet, supplanted the UNCG in determining the commission of genocide and how it was perpetrated and facilitated. ${ }^{35}$ Yet the ICJ finds no reason

to make any distinction of substance between "complicity in genocide," within the meaning of Article III, paragraph (e), of the Convention, and the "aid or assistance" of a State in the commission of a wrongful act by another State within the meaning of the aforementioned Article $16 .{ }^{36}$

This conclusion is highly suspect and reflects a misguided reliance on a source-Article 16 of the ILC document-that has no legal standing and yet plays a leading role in the court's investigation of the crime of genocide. According to the ICJ, the key test for complicity in genocide requires the court to "examine whether organs of the Respondent State, or persons acting on its instructions or under its direction or effective control, furnished 'aid or assistance' in the commission of the genocide in Srebrenica, in a sense not significantly different from that of those concepts in the general law of international responsibility."37 By equating complicity in genocide with aiding and abetting genocide, the ICJ has erroneously imposed upon the crime of complicity in genocide the standard required of one who aids or abets, the latter of which requires that there be a sharing of the principal perpetrator's intent and motive to commit genocide. 
A more faithful reading and understanding of complicity in genocide distinguishes between specific intent and specific motive. ${ }^{38}$ There is no question that the perpetrator of genocide must possess both the specific intent to destroy in whole or in part a protected group (sharing national, ethnic, racial, or religious character) and the specific motive to do so because of the group's identity as such. The "as such" requirement in art. 2 of the UNCG has always been its most distinguishing characteristic. In other words, it is because the group is of a single identity (national, ethnic, racial, or religious) that the perpetrator exercises the intent to destroy it. An aider or abettor of the perpetrator of genocide also shares the perpetrator's intention and motive to destroy the protected group. But if the protected group occupies territory sought by the perpetrator and is attacked solely to clear the territory of that group, then the discriminatory motive required by the UNCG would be missing (and a prosecutor might turn to crimes against humanity as the applicable criminal charge).

In contrast, the motive to destroy one of the protected groups as such need not be present for complicity in genocide. Like the crime of genocide, however, the intention to destroy in whole or in part a protected group must exist, whether the perpetrator is an individual or a government being complicit in genocide. Indeed, it is the absence of motive that is the raison d'être for the stand-alone crime of complicity in genocide and distinguishes it from aiding and abetting genocide. ${ }^{39}$ This is particularly true of governmental, as distinguished from individual, conduct. The ICJ should have examined more diligently whether the Serbian government provided significant support to the Bosnian Serbs from 1991 through 1995 knowing that such support would facilitate the genocidal aims of Bosnian Serb leaders but not necessarily sharing the motive to destroy any protected group (Bosnian Muslims) as such. Since the ICTY found that in Srebrenica the crime of genocide was committed by at least one individual, Bosnian Serb General Radislav Krstic (as an aider and abettor of the crime), the real question should have been whether the Serbian government facilitated genocide at Srebrenica through acts of complicity, not whether or not it perpetrated genocide.

The test for Bosnia would have been to prove before the ICJ that the Serbian government intended to destroy Bosnian Muslims at Srebrenica for the purpose of removing them from Srebrenica, not because of their protected group identity as such. ${ }^{40}$ The Bosnian Serb forces, as well as units like the Scorpions, were the vehicles for the activation of that intent, and yet the Serbian government need not be shown to share both the intent and the motive of the Bosnian Serb forces. Therefore, it would have been sufficient to show (1) that the Serbian government intended to destroy the Bosnian Muslims, in whole or in part, for strategic purposes (such as the ultimate creation of a larger Serbian state) and (2) that actions supporting such intent facilitated the perpetrators of genocide on the ground in Bosnia, who were exercising their own intention to destroy the Bosnian Muslims, in whole or in part, because of their religious or ethnic identity as such (and that the Serbian government was aware of that particular Bosnian Serb motive). This is not to conclude that the ICJ, after reviewing a more substantial body of evidence, would necessarily have found the Serbian government responsible for complicity in genocide. But the proper analytical methodology was never applied to determine whether or not such state responsibility existed.

The object and purpose of the UNCG to "prevent and to punish" the crime of genocide would be severely undermined if government leaders, such as those 
of Serbia and Montenegro in the early 1990s, knew that so long as they did not exhibit both the intent to destroy a protected group, in whole or in part, and the motive to destroy such a group because of its group identity, then their government would be free to facilitate the crime of genocide without incurring any consequence under arts. 2 or 3 of the UNCG. Indeed, under the ICJ's analysis, a government could avoid a technical finding of complicity in genocide and subsequently punish (or help others to punish) a few individuals as individual perpetrators, without ever incurring state responsibility under the law for facilitating, with specific intent, a genocidal campaign of extraordinary gravity and consequence. In the end, the government's objective of genocidal slaughters could be accomplished without establishing any state responsibility under the UNCG. Yet the same government could redeem itself under the convention's art. 1 responsibility by prosecuting (or helping others to capture and prosecute) a few fall guys (and, perhaps, who knows, making sure their families lived comfortably and happily ever after). This may indeed be the outcome if Belgrade finally turns Ratko Mladić over to the ICTY and, having avoided state responsibility for complicity in genocide, demonstrates its compliance with the ICJ's judgment that it must follow through on its responsibility to punish under art. 1 of the UNCG.

\section{The Elephant in the Room}

A broad swath of the majority's judgment describes atrocities in Bosnia and Herzegovina that the Bosnian government presented as evidence to the court. ${ }^{41}$ The majority relied heavily on the ICTY's examination of such evidence in cases for individual criminal responsibility heard by that tribunal. In no event, including Srebrenica, did the ICJ find the necessary specific intent to commit genocide on the part of the Serbian government. However, the court repeatedly inferred that a different conclusion might have been reached had it had jurisdiction to examine the same events through the prism of crimes against humanity or war crimes. ${ }^{42}$ In the absence of the high hurdle imposed by the specific intent requirement of genocide, it would probably have been easier to establish the responsibility of the Serbian government for the other atrocity crimes suggested by the court in the majority judgment.

Thus, if the court had had the opportunity to adjudicate not only allegations of genocide but also allegations of crimes against humanity and war crimes for which the Serbian government bears direct or indirect state responsibility, then the world might have read a very different, and more realistic, judgment by the ICJ majority on 26 February 2007. It would have been instructive to the international community for the majority to point out this factor more emphatically in its decision, at least as a "what if" scenario that it might have acknowledged it was precluded from exploring for jurisdictional reasons. In fact, however, we are left with the misleading impression that a judicial ruling has been made that Serbia as a state committed no crimes, because the ICJ majority found that it did not commit genocide. But what if the Serbian government perpetrated, or facilitated the commission of, crimes against humanity or war crimes in Bosnia and Herzegovina? Imagine how different the ICJ's judgment might have been if it had the jurisdiction to explore allegations relating to these categories of atrocity crimes.

The majority decision in Bosnia $v$. Serbia places in sharp focus the entire dilemma posed by the constraints of the UNCG in the realm of atrocity crimes and the need to establish state responsibility, with requisite penalties under the law, for crimes against humanity and serious war crimes. No international treaty exists for the totality of crimes against humanity that is comparable to the UNCG's coverage of the 
crime of genocide. As for war crimes, the Geneva Conventions of $1949^{43}$ and the 1977 Additional Protocols $\mathrm{I}$ and $\mathrm{II}^{44}$ do not contain compromissory clauses granting jurisdiction to the ICJ to adjudicate any dispute between or among states parties regarding the interpretation or application of the relevant treaty. Each of the Geneva Conventions treats violations of its provisions in a strictly collaborative manner, beginning with an inquiry, the procedure for which is either agreed upon by the interested parties or decided by an umpire selected by agreement among the interested parties. The relevant Geneva Convention then states, "Once the violation has been established, the Parties to the conflict shall put an end to it and shall repress it with the least possible delay." ${ }^{45}$ Nothing more is said about the state's responsibility or about what court, if any, has jurisdiction to adjudicate an allegation of a state party's non-compliance with the relevant Geneva Convention.

Significantly, Additional Protocol I requires that

A Party to the conflict which violates the provisions of the Conventions or of this Protocol shall, if the case demands, be liable to pay compensation. It shall be responsible for all acts committed by persons forming part of its armed forces. ${ }^{46}$

Nonetheless, neither the ICJ nor any other international court is granted any jurisdiction to adjudicate claims of governmental non-compliance with either Additional Protocol I or Additional Protocol II. The only clear way to seek payment of compensation for a violation as described in Protocol I would be through political, or perhaps economic or military, pressure.

Despite its historic confirmation that states can be held responsible for the crime of genocide under the UNCG, the ICJ's judgment in Bosnia v. Serbia reveals a major gap in the international law of state responsibility: There is no codified enforcement mechanism to hold states accountable for crimes against humanity and war crimes, which typically originate in and are managed by governments and are unleashed more frequently than genocide. These other atrocity crimes can be prosecuted against individuals in the ICC and in other international and hybrid criminal tribunals, but they remain strangely alien to forums of state responsibility.

The needs of international society have come full circle. State conduct was historically the central concern, and it has become so again. State responsibility requires a new codification exercise for crimes against humanity and war crimes, so that states can be held accountable for such crimes under the law in the same manner as the UNCG enables for state responsibility for genocide. In light of the convention's precedent and of the judgments of the international and hybrid criminal tribunals, the task is theoretically plausible. Capturing the political will to further discipline states in their conduct toward civilian populations and foreign military forces will be the greatest challenge. My bet is on the inevitability of the endeavor.

\section{Notes}

1. Case concerning Application of the Convention on the Prevention and Punishment of the Crime of Genocide (Bosnia and Herzegovina v. Yugoslavia), Judgment, 26 February 2007 [Bosnia v. Serbia].

2. Prosecutor v. Slobodan Milošević, ICTY-02-04-T.

3. Convention on the Prevention and Punishment of the Crime of Genocide, 9 December 1948, 78 U.N.T.S. 277, http://www.unhchr.ch/html/menu3/b/p_genoci.htm

(accessed 9 May 2007),

4. Bosnia v. Serbia, paras. 425-50. 
5. Outcome Document of the 2005 World Summit, UN Doc. A/RES/60/1 (24 October 2005), paras. 138-39. The term "atrocity crimes" covers genocide, crimes against humanity, and war crimes and is explained in David Scheffer, "Genocide and Atrocity Crimes," Genocide Studies and Prevention 1 (2006): 229-50; David Scheffer, The Merits of Unifying Terms: "Atrocity Crimes" and "Atrocity Law," Genocide Studies and Prevention 2.1 (2007): 91-95.

6. Bosnia v. Serbia, paras. 155-79.

7. "It is true that the concepts used in paragraphs (b) to (e) of Article III, and particularly that of 'complicity,' refer to well known categories of criminal law and, as such appear particularly well adapted to the exercise of penal sanctions against individuals. It would however not be in keeping with the object and purpose of the Convention to deny that the international responsibility of a State-even though quite different in nature from criminal responsibility - can be engaged through one of the acts, other than genocide itself, enumerated in Article III." Ibid., para. 167.

8. Case concerning Application of the Convention on the Prevention and Punishment of the Crime of Genocide (Bosnia and Herzegovina v. Yugoslavia), Joint declaration of Judges Shi and Koroma, 26 February 2007, paras. 1-4; Separate opinion of Judge Owada, 26 February 2007, paras. 38-73; Separate opinion of Judge Tomka, 26 February 2007, paras. 37-61; Declaration of Judge Skotnikov, 26 February 2007; Separate opinion of Judge ad hoc Kreča, 26 February 2007, paras. 126-29, 131-37.

9. "In the light of its review of the factual evidence before it of the atrocities committed in Bosnia and Herzegovina in 1991-1995, the Court has concluded that, save for the events of July 1995 at Srebrenica, the necessary intent required to constitute genocide has not been conclusively shown in relation to each specific incident." Bosnia v. Serbia, para. 370.

10. Prosecutor v. Krstic, Judgment, ICTY-98-33-T (2 August 2001), cited in Bosnia v. Serbia, paras. 278-97. Although the ICJ also cites the Trial Chamber's judgment in Prosecutor $v$. Blagojević, ICTY-02-60-T (17 January 2005), the ICTY Appeals Chamber reversed Vidoje Blagojević's conviction for complicity in genocide: Prosecutor v. Blagojević and Jokić, Judgment, ICTY-02-60-A (9 May 2007), paras. 119-24.

11. Bosnia v. Serbia, para. 172.

12. ICJ Vice-President Awn Shawkat Al-Khasawneh emphasizes the findings of inferred intent to commit genocide by both the ICTY and the International Criminal Tribunal for Rwanda, pointing in particular to judgments in Jelisic, Krstić, Rutaganda, Akayesu, Musema, and Kayishema. Case concerning Application of the Convention on the Prevention and Punishment of the Crime of Genocide (Bosnia and Herzegovina v. Yugoslavia, Dissenting opinion of Vice-President Al-Khasawneh, 26 February 2007, paras. 43-47 [Al-Khasawneh Dissent].

13. Bosnia v. Serbia, para. 178.

14. Ibid., para. 179.

15. Ibid., para. 370.

16. Ibid., para. 376 .

17. Ibid., para. 371 .

18. Ibid., para. 372 .

19. "That the ICTY has not found genocide based on patterns of conduct in the whole of Bosnia is of course not in the least surprising. The Tribunal only has jurisdiction to judge the individual criminal liability of particular persons accused before it, and the relevant evidence will therefore be limited to the sphere of operations of the accused.... While the Court is intent on adopting the burden of proof relevant to criminal trials, it is not willing to recognize that there is a fundamental distinction between a single person's criminal trial and a case involving State responsibility for genocide. The Court can look at patterns of conduct throughout Bosnia because it is not constrained by the sphere of operations of any particular accused-and it should have done so." Al-Khasawneh Dissent, para. 42.

20. See Marlise Simons, "Genocide Court Ruled for Serbia Without Seeing Full War Archive," New York Times, 9 April 2007, A1. 
21. Statute of the International Court of Justice, annexed to the UN Charter, 26 June 1945, U.N.T.S. 993, art. 49.

22. "[T]he Court was alerted by the Applicant to the existence of 'redacted' sections of documents of the Supreme Defence Council of the Respondent. Regrettably, the Court failed to act although, under Article 49 of its Statute, it has the power to do so. It is a reasonable expectation that those documents would have shed light on the central questions of intent and attributability...' Although the Court has not agreed to either of the Applicant's requests to be provided with unedited copies of the documents, it has not failed to note the Applicant's suggestion that the Court may be free to draw its own conclusions. It should be observed that Article 49 of the Statute provides that 'formal note should be taken of any refusal' and not of the Applicant's suggestion. In addition to this completely unbalanced statement that does not the meet the requirement of Article 49, no conclusions whatsoever were drawn from noting the Respondent's refusal to divulge the contents of the unedited documents. It would normally be expected that the consequences of the note taken by the Court would be to shift the onus probandi or to allow a more liberal recourse to inference as the Court's past practice and considerations of common sense and fairness would all demand." Al-Khasawneh Dissent, para. 35 (emphasis added).

23. Prosecutor v. Milosevic, ICTY-02-54-T, Judgment (16 December 2003), 30494-95.

24. Bosnia v. Serbia, para. 437.

25. "General Mladić's decisive role in the Srebrenica genocide, the close relationship between General Mladić and President Milošević, the influential part President Milošević played in negotiations regarding Srebrenica (both before and after the genocide), and his own statements ... each taken alone, might not amount to proof of President Milošević's knowledge of the genocide set to unfold in Srebrenica. Taken together, these facts clearly establish that Belgrade was, if not fully integrated in, then fully aware of the decisionmaking processes regarding Srebrenica, while the Republika Srpska itself was excluded. Even after the fact, negotiations following the fall of Srebrenica and the genocide committed there were held simultaneously with General Mladić and President Milošević. There can be do doubt that President Milošević was fully appraised [sic] of General Mladić's (and the Bosnian Serb army's) activities in Srebrenica through the takeover and massacres." Al-Khasawneh Dissent, para. 51.

26. Bosnia v. Serbia, paras. 389-95; Al-Khasawneh Dissent, paras. 52-55.

27. Bosnia v. Serbia, para. 377.

28. Ibid., para. 378. In dissent, Vice-President Al-Khasawneh writes, "Indeed, the opposite conclusion from that reached by the Court in paragraph 378 is supported by the cited jurisprudence [prior ICJ judgments]. To the extent that the effect of a unilateral act depends on the intent behind it and the context within which it was made, one need only consider this: the Serbian Government at the time was attempting to distance itself-as a new and democratic régime-from the régime which had come before it, in light of the revelation of horrible crimes committed by paramilitary units (the Scorpions) on national Serbian and international television. The intent was to acknowledge the previous régime's responsibility for those crimes, and to make a fresh start by distancing the new régime therefrom. A clearer intention to 'admit' past wrongs cannot be had." Al-Khasawneh Dissent, para. 58. He concludes, "The Serbian Council of Ministers' statement, taken in the context of the other evidence available to the Court, certainly amounts to an admission of the responsibility of President Milošević's regime for the massacres in Srebrenica, which the Court has determined amount to genocide." Ibid., para. 61.

29. Report of the International Commission of Inquiry on Darfur to the United Nations Secretary-General, Pursuant to Security Council Resolution 1546 of 18 September 2004 (25 January 2005), paras. 489-522, http://www.un.org/News/dh/sudan/com_inq_darfur.pdf (accessed 8 May 2007).

30. Bosnia v. Serbia, para. 373 (emphasis added).

31. Ibid., para. 277.

32. Al-Khasawneh Dissent, para. 40. 
33. Responsibility of States for Internationally Wrongful Acts, UN General Assembly Resolution 56/83, UN Doc. A/56/10 (12 December 2001), http://untreaty.un.org/ilc/texts/ instruments/english/draft\%20articles/9_6_2001.pdf (accessed on 9 May 2007). The ICJ majority refers to this document as "the ILC's Articles on State Responsibility," which was its title before 2001.

34. Bosnia v. Serbia, para. 420.

35. The ILC articles deliberately do not include any provision that explicitly addresses "international crimes" (an option that was rejected); instead they refer to "a peremptory norm of international law." See Responsibility of States, arts. 41 and 42.

36. Bosnia v. Serbia, para. 420.

37. Ibid. (emphasis added).

38. I am indebted to Daniel M. Greenfield, one of my students at Northwestern University School of Law, who researched and wrote a paper titled "The Crime of Complicity in Genocide" in the spring of 2007, for his insights into some of the issues pertaining to complicity in genocide.

39. Judge Keith offers the most coherent explanation in his separate declaration, which disputes the way in which the majority addresses complicity in genocide: "[In the drafting record of the Genocide Convention in 1948,] that history is better read as requiring that the alleged accomplice know that the principal perpetrator has the necessary intent, not that the alleged accomplice share it.... The discussion on the proposed amendment (which was to add the world 'deliberate' before 'complicity' but which was withdrawn on the basis that complicity in genocide must be 'deliberate') indicates that the actions had to be 'deliberate' in the sense of knowing of the perpetrator's intent; the intent did not have to be shared." Continuing, Judge Keith writes, "I now turn to the facts and to the question whether the Applicant has shown that the Respondent, knowing of the perpetrator's genocidal intent, continued to supply the perpetrators with the means to facilitate the realization of that intent. There can be no possible dispute about that supply and its continuation." Case concerning Application of the Convention on the Prevention and Punishment of the Crime of Genocide (Bosnia and Herzegovina v. Yugoslavia), Declaration of Judge Keith, 26 February 2007, paras. 7-8. In concluding that Serbia was complicit in genocide at Srebrenica in July 1995 in breach of art. 3(e) of the UNCG, Judge Keith describes the discussions and negotiations between President Milošević and General Mladić: "Given President Milošević's overall role in the Balkan wars and his knowledge, his specific relationship with General Mladić, and his involvement in the detail of the negotiations of 14 and 15 July [1995], by that time he must have known of the change in plans made by the VRS command on 12 or 13 July [1995] and consequently he must have known that they had formed the intent to destroy in part the protected group. I am convinced that that knowledge of the Respondent [Serbia] is proved to the necessary standard stated by the Court in its Judgment (paragraph 209).” Ibid., para. 15. Judge Bennouna shared the same view, and his declaration, written in French, was summarized by the court as stating that he "considers that all the elements were present to justify a finding by the Court of complicity on the part of the authorities in Belgrade: not only the various forms of assistance they provided to Republicka Srpska and its army but also the knowledge they had or should have had of the genocidal intention of the principal perpetrator of the massacre at Srebrenica." Case concerning Application of the Convention on the Prevention and Punishment of the Crime of Genocide (Bosnia and Herzegovina v. Yugoslavia), Summary of the judgment of 26 February 2007, Annex to Summary 2007/2, http://www. icj-cij.org/docket/index.php?sum $=667 \&$ code $=$ bhy $\& \mathrm{p} 1=3 \& \mathrm{p} 2=3 \&$ case $=91 \& \mathrm{k}=\mathrm{f} 4 \& \mathrm{p} 3=5$ (accessed 14 May 2007). Vice-President Al-Khasawneh approaches the issue holistically: "The Court likewise failed to appreciate the definitional complexity of the crime of genocide and the need for a comprehensive approach in appreciating closely related facts, the role of General Mladić and the Scorpions in Srebrenica being a prime example. Moreover, where certain facts did not fit the Court's conclusions, they were dismissed with no justification, the statement of the new government of Serbia being also a case in point. I am certain that 
as far as Srebrenica is concerned, FRY responsibility as a principal or as an accomplice is satisfied on the facts and in law. I am of the opinion also that with regard to other parts of Bosnia and Herzegovina, had the Court followed more appropriate methods of assessing the facts, there would have been, in all probability, positive findings as to Serbia's international responsibility." Al-Khasawneh Dissent, para. 62.

40. The distinction lies between destroying the Bosnian Muslims for a strategic purpose (in this case, to get them out of the Srebrenica region for good) and destroying them simply because they are Bosnian Muslims-a motive that, of course, could easily be tied by the Bosnian Serbs to a strategic one that also suits their objectives. The strategic purpose can serve the purposes of complicity in genocide, which might be advantageous to the Serbian government, while the second goal serves the purpose of raw genocide-destroying a group as such because it is that group, and not necessarily for any strategic purpose. If it can be shown that the Serbian government had a strategic purpose and that destroying the group of Bosnian Muslims served that purpose, and that Serbia also knew that the Bosnian Serbs had another motive-namely, to destroy the group as such (and Srebrenica was either a prop to accomplish that task or perhaps even a strategic goal as well), then the two purposes are joined in the crime of genocide. One party, the Bosnian Serbs, commit genocide (or, in the case of General Krstić, aid and abet genocide). The Serbian government's actions must then be proved to reflect its complicity in such genocide.

41. Bosnia v. Serbia, paras. 242-367.

42. For example, in examining evidence of "killing members of the protected group" under art. 2(a) of the UNCG, "the Court finds that it is established by overwhelming evidence that massive killings in specific areas and detention camps throughout the territory of Bosnia and Herzegovina were perpetrated during the conflict.... The Court thus finds that it has been established by conclusive evidence that massive killings of members of the protected group occurred and that therefore the requirements of the material element, as defined by Article II(a) of the Convention, are fulfilled.... The Court is however not convinced, on the basis of the evidence before it, that it has been conclusively established that the massive killings of members of the protected group were committed with the specific intent (dolus specialis) on the part of the perpetrators to destroy, in whole or in part, the group as such. The Court has carefully examined the criminal proceedings of the ICTY and the findings of its Chambers, cited above [in the judgment], and observes that none of those convicted were found to have acted with specific intent (dolus specialis). The killings outlined above [in the judgment] may amount to war crimes and crimes against humanity, but the Court has no jurisdiction to determine whether this is so. In the exercise of its jurisdiction under the Genocide Convention, the Court finds that it has not been established by the Applicant that the killings amounted to acts of genocide prohibited by the Convention." Bosnia v. Serbia, paras. 276-77.

43. Convention for the Amelioration of the Condition of the Wounded and Sick in Armed Forces in the Field, 12 August 1949, 75 U.N.T.S. (1950) 31 [First Geneva Convention]; Convention for the Amelioration of the Condition of Wounded, Sick and Shipwrecked Members of Armed Forces at Sea, 12 August 1949, 75 U.N.T.S. (1950) 85 [Second Geneva Convention]; Convention Relative to the Treatment of Prisoners of War, 12 August 1949, 75 U.N.T.S. (1950) 135 [Third Geneva Convention]; Convention Relative to the Protection of Civilian Persons in Time of War, 12 August 1949, 75 U.N.T.S. (1950) 287 [Fourth Geneva Convention].

44. Protocol Additional to the Geneva Conventions of 12 August 1949, and Relating to the Protection of Victims of International Armed Conflicts, 12 December 1977, 1125 U.N.T.S. (1979) 3 [Additional Protocol I]; Protocol Additional to the Geneva Conventions of 12 August 1949, and Relating to the Protection of Victims of Non-International Armed Conflicts, 12 December 1977, 1125 U.N.T.S. (1979) 609 [Additional Protocol II].

45. See First Geneva Convention, art. 52; Second Geneva Convention, art. 53; Third Geneva Convention, art. 132; Fourth Geneva Convention, art. 149.

46. Additional Protocol I, art. 91. Additional Protocol II contains no comparable compensation provision. 